\title{
Managers' attitude and organizational culture for social media use in supply chain efficiency and responsiveness
}

\author{
Muhammed Kürşad Özlen ${ }^{\mathrm{a}}$ \\ a San Diego State University, Imperial Valley Campus, California, USA
}

\begin{abstract}
Research Question: The research model proposes that (a) Managers' Attitude and Organizational Culture are fundamental in using Social Media for supply chain activities, and (b) Social Media Use increases Responsiveness and Operational Efficiency.
\end{abstract}

Motivation: IT professionals are continuously improving advanced software programs for business activities to leverage their activities and benefits. Beside that there are Social Media platforms which provide online presence to the company and enhance communication of people. Literature has studies regarding the use of Social Media for supply chain activities which mainly focus on enhancing marketing and customer relationships and the integration of supply chains. However, there is scarcity of research from organizational and employee perspectives.

Idea: This study aims to see the influence of Managers' attitude and Organizational culture for Social Media usage of supply chain professionals in their supply chain activities.

Data: In order to test the relationships, a survey is conducted among 200 employees/professionals employed across $44 \mathrm{BiH}$ SMEs which are parts of existing supply chains from various sectors.

Tools: Descriptive statistics, confirmatory factor analysis-CFA and regression analysis are employed by using SPSS (version 20) software program.

Findings: $\mathrm{BiH}$ companies have high operational efficiency and positive considerations about all model components. The results also show that the model works well in all dimensions.

Contribution: This research serves as a good basis/template for similar future studies especially in $\mathrm{BiH}$ environment. Besides that, since there is few research from organizational and employee perspectives, this study purposes to see the impact of Managers' attitude and Organizational Culture for Social Media usage of supply chain professionals in their supply chain activities. 
Keywords: small and medium enterprises; social media use; operational responsiveness; operational efficiency; survey.

JEL codes: L86, M11

\section{Introduction}

Given that supply chains and their management become extremely important as a result of fast changes in national/global markets and customer behaviors, supply chains and their activities take the attention of researchers and practitioners. Companies are employing various strategies and tools in order to facilitate their activities by employing innovative tools and ideas in their particular supply chains; and all chain members tend to become responsive for new trends in order to gain benefits in their supply chain activities.

One of the newest and most effective ways of enhancing business in terms of responsiveness and strength of chain ties is Social Media. Social media is also one of the most important tools in transforming the way organizations approach to their operations, supply chain partners, customers etc. (Aral et al., 2013). The research on keeping up with the latest trends and using innovative tools/techniques such as Social Media in organizational activities has become a hot topic. Social Media is useful in providing higher visibility, easier promotion and wider access to services and products in enhancing the integration of supply chains. However, Supply chain management literature is weak in studying social media use for work (Chae, 2015; van Zoonen et al., 2017) especially regarding the employees who have close interaction with supply chain partners (Huo et al., 2015).

Supply Chain Management literature mainly focuses on the use of Social Media for supply chain activities regarding enhanced marketing and customer relationships and the integration of supply chains. However, there is few research from organizational and employee perspectives. This study purposes to see the impact of Managers' attitude and Organizational Culture for Social Media usage of supply chain professionals in their supply chain activities.

This study is motivated to identify important points regarding the use of Social Media in supply chain activities and proposes relationships among the identified constructs. The research model of Social Media use in supply chain activities is tested based on the perceptions of Bosnian SMEs' professionals. The model proposes that (a) Managers' Attitude and Organizational Culture are essential for Social Media use in supply chain activities, and (b) used Social Media contributes to both Operational Responsiveness and Efficiency. In order to test the relationships, a survey is conducted among 200 employees/professionals across several BiH SMEs. 
Following sections provide the literature about the research model components, social media use in $\mathrm{BiH}$, data and methodology, analysis, results and conclusion.

\section{Literature Review}

In order to carefully plan the research about the use of social Media in small and medium enterprises in $\mathrm{BiH}$ and to develop a survey questionnaire, the relevant past work has been reviewed. The following sections provide a summary of information attained from the various literature sources.

\subsection{Social Media}

Social media, Internet-based applications, allows the development of user-generated information and provides a social interaction medium for users. Social media is also referred as Web 2.0 (O’Reilly, 2005) or Enterprise 2.0 (e.g. McAfee, 2006). Highly developed Internet technologies enable people to have direct access to information through social media (Tybout \& Calder, 2010). Social media connects people (as social beings) and media (the tools and the delivery ways) for social interaction by using accessible and scalable communication technologies (Markova \& PetkovskaMirčevska, 2013).

Social media, a group of Internet-based applications as a part of a larger social framework, allows the creation and exchange of user-generated content through ideological and technological foundations of Web 2.0 (Kaplan \& Haenlein, 2010) for a shared or collaborative goal. Collaborative Web 2.0 technologies, especially social media, provide a more flexible communication, collaboration and sharing medium for people (Enders et al., 2008; Hutchins \& Rodriguez, 2018).

Social media is also consumer generated media (CGM) where customers, target audience, happily spend time in a conversation about the business, such as brand outposts, with the people who have common interests (Markova \& PetkovskaMirčevska, 2013).

Mobile applications are developed for social media providing mechanisms to build internal social networks (e.g. Line, WhatsApp) (Salo, 2017). The research identified that $100 \%$ of business decision-makers use social media for their professional objectives (Reiss-Davis, 2013).

\subsection{Use of Social Media in Supply Chains}

Given the complexity of supply chains as media with too many connections and relationships among individuals, groups and social units, it is necessary to understand their multi-dimensional environment (Choi \& Hong, 2002). 
Social Media can be useful in generating risk alerts, enhancing responsiveness by increasing adjustment in each area and facilitating recovery and system redesign to diminish future supply chain disruptions (O'leary, 2011). Moreover, Social Media are useful in gathering information, building and maintaining relationships and ultimately developing trust and communication capabilities through the network.

According to Casemore (2012), the five key benefits of social media in the supply chain are (1) Creating Knowledge Media in order to rapidly capture and respond to customer feedback both internally (inventory, warehousing, and procurement departments) and externally (suppliers and contractors); (2) Speed and Inspection Harmony across supply chain; (3) Portable Information Vaults-instant information access; (4) Replacing Collaboration with Community (closer relationships with key suppliers); (5) Constructing an Innovation Platform by engaging suppliers.

Developing long-term and collaborative relationships with strategic suppliers is suggested for a focal buying firm (Bensaou, 1999; Chen, Paulraj \& Lado, 2004; Dyer \& Singh, 1998; Gadde \& Snehota, 2000). Social media provides rich source of information for companies in supply chains (Elghannam et al., 2018). Social Media is useful to enhance supply chain integration by providing mutual trust, reciprocal commitment, and repeated communication among network members (Cheng, 2010; Madison, 2012). Based on mutual trust, openness, shared risks and rewards, cooperation with other companies in supply chain (SC) companies leverage their competitive advantage (Christopher, 1998; Gunasekaran et al., 2001; Ozkul \& Barut, 2009; Swain \& Cao, 2019). The increasing use of social media has also offered companies of all sectors the opportunity to keep in contact with their consumers (Elghannam \& Mesias, 2019).

Social media enhances capturing information associated with various supply chain events such as sending and receiving goods. Captured information can be integrated into supply-chain transaction-processing systems (O'leary, 2011). Therefore, information can be quickly communicated and shared in a special context which facilitates building 'relationships' among supply-chain participants that are not normally accessible.

Given that Customer relationship management (CRM) is one of the main supply chain processes enhancing the relationships with customers, the significance of Social CRM is continuously increasing (Markova \& Petkovska-Mirčevska, 2013). While the organization is controlling the relationships in traditional CRM, in Social CRM the power is with the customer who influences others in his or her social network (Markova \& Petkovska-Mirčevska, 2013).

The initial step for a Social CRM strategy is to understand the reasons of customer engagement with the company via social media so that companies can assess their social media initiatives (Markova \& Petkovska-Mirčevska, 2013). 
The use of social Media for supply chain activities, especially through social CRM, is expected to gradually enhance organizational effectiveness through the entire chain by collecting necessary data for the activities. Furthermore, through instant information access, the entire supply chain can benefit for all its transactions such as electronic purchase orders, order status, order receipts, invoices, and payment status (Markova \& Petkovska-Mirčevska, 2013).

Beside the increasing trend in social media use in B2B (among supply chain partners) (Chan et al., 2017; Loiacono \& McCoy, 2018), it is still in its early phases (Serbetcioglu \& Göçer, 2020). After examining the social media profiles of logistics service providers and their social media use in enhancing their services, Serbetcioglu and Göçer (2020) identify that logistics service providers use multiple social media channels with different motives and they have unique social media profiles. Social media use is generally preferred for marketing and customer relationship purposes (Ang, 2011).

\subsection{Organizational Culture and Management Support}

Supply-chains have weak social media adoption (TodaysTrucking, 2010) and it is still emerging yet. SCC (Supply Chain Council) (2010) suggests five key events (plan, make, source, deliver and return) for the use of social media in a supply-chain setting process. O'leary (2011) suggests (1) the use of social media in supply-chain practices and development of a context for the practices, (2) building relationships among supply-chain participants, and (3) the integration of traditional knowledge management with generated knowledge from social media. O'leary (2011) also suggests the use of social media for supply-chain architectures as additional information flows.

There are few studies regarding the impact of social media usage from organizational context perspective (Leonardi \& Vaast, 2016). Social media use increases employees' comfort regarding work schedule, location control and flexibility (Cavazotte et al., 2014; van Zoonen et al., 2017). External factors such as business climate and network structures can affect SM usage (Quinton \& Wilson, 2016).

Executives positively approach social media use to gather information about products and services (Ramos \& Young 2009; Zhang \& Piramuthu 2016), to understand the stakeholders' perceptions about their actions and to see the reflections of their perceptions in social media. Since social media provides numerous advantages to managers in identifying their customers' profiles and demands, they can define target segments and adapt their strategies to meet customer expectations (Elghannam \& Mesias, 2019).

There is little research about social media use in supply chains and its effect on supply chain organizations and their employees (Chan et al., 2017). The existing 
research on social media use in supply chain management mainly focuses on its benefits as a result of enhanced communication and coordination (Shang et al., 2017) which improves supply chain efficiency (Perez-Luno et al., 2019). However, we know less about the attitudes of supply chain professionals and their work environment (Yee et al., 2008). This is a crucial point because human factors can lead to operational risks in disrupting supply chain activities (Jiang et al., 2009; Zsidisin et al., 2005). Research from the employee perspective accordingly is an important however under-studied research issue (Tang et al., 2019).

Based on the discussion in this section, we propose that

H1: "Organizational Culture" positively influences "Social Media Use"; and

H2: "Managers' Attitude" positively impacts "Social Media Use".

\subsection{Operational Efficiency and Responsiveness}

Efficient communication/coordination is critical in supply chain management (SCM) as they are directly linked to supply chain performance (Elghannam \& Mesias, 2019). Therefore, as a continuous communication and data collection tool, social media is useful to enhance the performance of supply chains (Gebremikael et al., 2020).

Swain and Cao (2019) explore the relationship between elements of company social media content and supply chain performance in terms of information sharing, collaboration, trust, and commitment. According to the results, information sharing and collaboration are positively related to supply chain performance.

Supply chain members may continue to use social media and stay connected after work hours for work purposes (Tang et al., 2019; Mullan \& Wajcman, 2019). This phenomenon is termed social media connectivity (SMC) (Richardson \& BenbunanFich, 2011) which increases the expectations for supply chain professionals to stay connected to social media in order to sustain supply chain efficiency (Lam et al., 2016; Tang et al., 2019).

Following this section, we can propose that

H3: "Social Media Use" has positive effect on "Supply Chain Efficiency"; and

H4: "Social Media Use" positively impacts "Supply Chain Responsiveness".

\subsection{Social Media and SMEs in Bosnian Setting}

Using Social Media in SCM activities is relatively new for Bosnian SMEs. IPA National Program (2009) has aimed to support the development of the small and 
medium enterprises (SMEs) in BiH through analyzing the overall SME market by showing its main strengths and weaknesses. Based on the results, about $45 \%$ of the local SMEs have switched to using social Media for their supply chain activities. Its results provide that SMEs have expanded their activities through social Media which enable easier access to customers and faster ways of doing business.

A local research, by Avdagić et al. (2008), claims that some of the largest SMEs in Bosnia and Herzegovina have developed strategies during the financial crisis in expanding their activities and promote their services and/or products. According to them, due to the obstacles and problems because of the crisis, most SMEs located in Bosnia and Herzegovina are forced to find out new options to expand/maintain their supply chain activities. They furthermore report that Facebook boom, helpful for many international SMEs, has been disregarded much by the local SMEs.

Some studies report the inefficiency of Bosnian SMEs in terms of their supply chain activities and innovativeness. The Development of Corporate Social Responsibility in Central Eastern Europe Project analyzes and technically assists the agencies and foreign countries (UNIDO, 2007). The project, after analyzing BiH SMEs, asserts that investment problems, communication gaps and lack of innovation are among the main problems of SMEs in BiH in terms of their supply chain activities.

USAID (2009) provides in-depth analysis about the SME market in $\mathrm{BiH}$ and recommends larger use of information technology (IT), including social Media, to facilitate activities of SMEs. The program also suggests that since most business in $\mathrm{BiH}$, and the world is accomplished through the internet, and since the popularity of Social Media is rapidly increasing, enterprises in $\mathrm{BiH}$ are required to invest more regarding the use of social Media in their supply chain activities.

Moreover, OECD (2009) presents various technical projects related to SME market and SME development in $\mathrm{BiH}$ and they advise connecting companies' supply chain activities with Social Media. Additionally, UNECE (2010) analyzes various supply chain management activities of $\mathrm{BiH}$ SMEs and recommends a range of solutions for larger business development including use of Social Media. The regional and European participants of the conference emphasize that in order to achieve larger business development; BiH SMEs must disclose and take their activities online.

After analyzing various concerns of $\mathrm{BiH}$ SMEs, customer expectations, and various research and innovation opportunities including a complete business analysis of various technology sources (such as internet/social Media), Dimitrijevic and Rodic (2011) suggest the use of Social Media in enhancing supply chain activities.

Based on various World Bank reports' findings and observations, Hadžić and Pavlović (2012) report that World Bank offers solid solutions and technical advices to local SMEs about the use of Social Media in supply chain activities. According to 
the results of their conducted survey on various managers of SMEs about their habits and preferences, as well as their personal and company specific weaknesses, Hadžić and Pavlović (2012) report that BiH SME market is the third most developed market in the region according to World Bank results.

\section{Research Model}

By considering the above discussion and reviewed works, we identified important points regarding the use of Social Media and propose relationships among the identified constructs (Table 1). The table provides the basic used references while structuring the research and developing survey questions.

Table 1. Variables of the Model

\begin{tabular}{cc}
\hline Variable Name & References \\
\hline Managers' Attitude & IPA National Program (2009) \\
Ramos and Young (2009) & Zhang and Piramuthu (2016) \\
Use of Social Network & Dimitrijevic and Rodic (2011) \\
& Elghannam et al. (2018) \\
Operational & \\
Responsiveness & Avdagić et al. (2007) \\
& Gebremikael et al. (2020) \\
Cheng and Krumwiede (2018) & \\
Operational Efficiency & UNECE (2010) \\
& Gebremikael et al. (2020) \\
& Cheng and Krumwiede (2018) \\
Organizational Culture & \\
& Leonardi and Vaast (2016) \\
& Quinton and Wilson (2016) \\
&
\end{tabular}

The research model proposes that (a) Managers' Attitude and Organizational Culture enhance the use of Social Media in supply chain activities, and (b) using Social Media leverages Operational Responsiveness and Efficiency. 


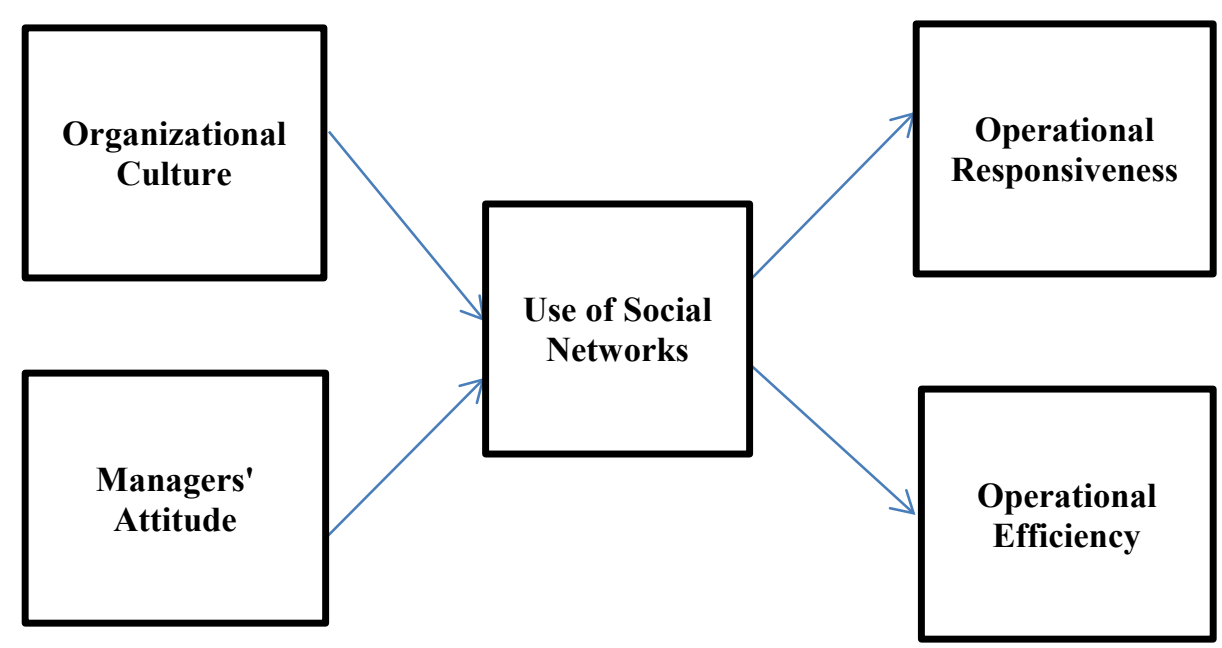

Figure 1 Research Model

\section{Data and Methodology}

We preferred a survey study for data collection. The survey is improved by the help of important points derived from reviewing literature. All the points are collected under proper dimensions according to the suggestions of the literature. The improved survey is checked for grammar errors and evaluated by three business faculty academics for the validity and consistency. According to their suggestions, it took its final form.

In order to test the relationships among the constructs, the improved questionnaire is distributed to 200 professionals/employees through $44 \mathrm{BiH}$ small and medium enterprises including joint stock companies, limited liability companies, a utility company, a technology company, and an academic institution. We adopted convenient sampling while selecting the companies which are parts of supply chains. However, we did not differentiate them regarding their characteristics such as their industry, service/production orientation, etc. The respondents filled the survey voluntarily. In order to increase the response rate, survey collector helped the respondent in filling up the questionnaire. Therefore, all distributed surveys are collected with $100 \%$ response rate. The questionnaire/survey includes five sections, each having 4 questions. Each question is assigned a 1 to 5 grading scale with $1=$ strongly disagree and $5=$ strongly agree. The number of useful responses is fixed to 200 and the conduction of the survey is stopped after this number. In this research, it can be asserted that due to close cooperation and contact with interviewed institutions and employees, a perfect response rate (100\%) is achieved.

Descriptive statistics, confirmatory factor analysis-CFA and regression analysis are employed by using SPSS (version 20) software program. 


\section{Results}

\subsection{Demographics}

The respondent characteristics are evaluated through four categories including type of organization/business, department within the organization, gender and age. The survey is conducted on 200 applicants ( 115 males and 85 females). The positions of the respondents vary through the organizations. They have generally administrative (88/200) and clerical (78/200) positions. The remaining are from production and marketing/sales departments. Most of the visited organizations are limited liability companies (26) and joint stock companies (7) and the respondents are mainly from limited liability companies (104/200) followed by Joint Stock Companies (33/200).

\subsection{Descriptive Analysis}

According to the results, respondents have positive considerations about the variables. They believe that the managers' attitude towards Social Media Use is fine, organizational culture is supportive for using Social Media, they use Social Media, their supply chain is responsive and their operations are highly efficient (see mean in Table 2).

\subsection{Research Model Test}

The dimensions of research model are also evaluated by factor analysis in SPSS program. Item loadings are checked and some of them are deleted if their loadings were under 0.50. At the end, one item from "Operational Responsiveness" dimension and one item from "Use of Social Media" dimension are removed because of weak loadings. According to the results, the dimensions are strong in terms of reliability (Cronbach's Alpha results are quite high) and the validity (item-factor correlations). Moreover, the data is satisfactory in order to run analysis (KMO measures) (see Table 2).

Table 2 CFA Results

\begin{tabular}{|c|c|c|c|c|c|}
\hline \multirow{2}{*}{ Factor } & \multirow{2}{*}{$\begin{array}{l}\mathrm{N} \text { of } \\
\text { Items }\end{array}$} & \multirow{2}{*}{ Mean } & $\begin{array}{l}\text { Item-Factor } \\
\text { Correlations }\end{array}$ & $\begin{array}{l}\text { Sampling } \\
\text { Adequacy }\end{array}$ & $\begin{array}{l}\text { Reliability } \\
\text { Statistics }\end{array}$ \\
\hline & & & $\begin{array}{l}\text { Interval for Item } \\
\text { Loadings }\end{array}$ & KMO Measure & $\begin{array}{c}\text { Cronbach's } \\
\text { Alpha }\end{array}$ \\
\hline $\begin{array}{l}\text { Managers' } \\
\text { Attitude }\end{array}$ & 4 & 3.23 & $0.823-0.869$ & 0.795 & 0.864 \\
\hline $\begin{array}{c}\text { Operational } \\
\text { Responsiveness }\end{array}$ & 3 & 3.33 & $0.708-0.848$ & 0.79 & 0.774 \\
\hline $\begin{array}{c}\text { Use of Social } \\
\text { Media }\end{array}$ & 3 & 3.25 & $0.805-0.833$ & 0.774 & 0.864 \\
\hline $\begin{array}{l}\text { Organizational } \\
\text { Culture }\end{array}$ & 4 & 3.12 & $0.787-0.846$ & 0.809 & 0.839 \\
\hline
\end{tabular}


Managers' Attitude and Organizational Culture for Social Media Use in Supply

Chain Efficiency and Responsiveness

\begin{tabular}{cccccc}
\hline \multirow{2}{*}{ Factor } & $\begin{array}{c}\text { N of } \\
\text { Items }\end{array}$ & Mean & $\begin{array}{c}\text { Item-Factor } \\
\text { Correlations }\end{array}$ & $\begin{array}{c}\text { Sampling } \\
\text { Adequacy }\end{array}$ & $\begin{array}{c}\text { Reliability } \\
\text { Statistics }\end{array}$ \\
\cline { 4 - 6 } & & $\begin{array}{c}\text { Interval for Item } \\
\text { Loadings }\end{array}$ & KMO Measure & $\begin{array}{c}\text { Cronbach's } \\
\text { Alpha }\end{array}$ \\
\hline $\begin{array}{c}\text { Operational } \\
\text { Efficiency }\end{array}$ & 4 & 4.61 & $0.707-0.840$ & 0.739 & 0.776 \\
\hline
\end{tabular}

After determining the strengths of model constructs by CFA, we test the proposed relationships by employing Linear Regression analysis. According to the results (Table 3), all relationships are significantly positive indicating that all the hypotheses are supported.

Table 3 Regression Results

\begin{tabular}{ccccc}
\hline \multicolumn{2}{c}{ Relations } & $\begin{array}{c}\text { Adjusted R } \\
\text { Square }\end{array}$ & $\begin{array}{c}\text { Standardized } \\
\text { Coefficients }\end{array}$ & Sig. \\
\hline Dependent & Independent & 0,585 & 0,212 & $* * *$ \\
Organizational Culture & Use of Social Media & 0,678 & $* * *$ \\
\hline Managers' Attitude & Operational & 0,233 & 0,487 & $* * *$ \\
Use of Social Media & $\begin{array}{c}\text { Responsiveness } \\
\text { Operational Efficiency }\end{array}$ & 0,502 & 0,711 & $* * *$ \\
\hline
\end{tabular}

Regression equations reveal that (1) "Organizational Culture" significantly influences "Use of Social Media" while "Managers' Attitude" has strong effect on the use; and (2) "Use of Social Media" has strong positive impact on "Operational Efficiency" and high positive effect on "Operational Responsiveness" (Figure 2).

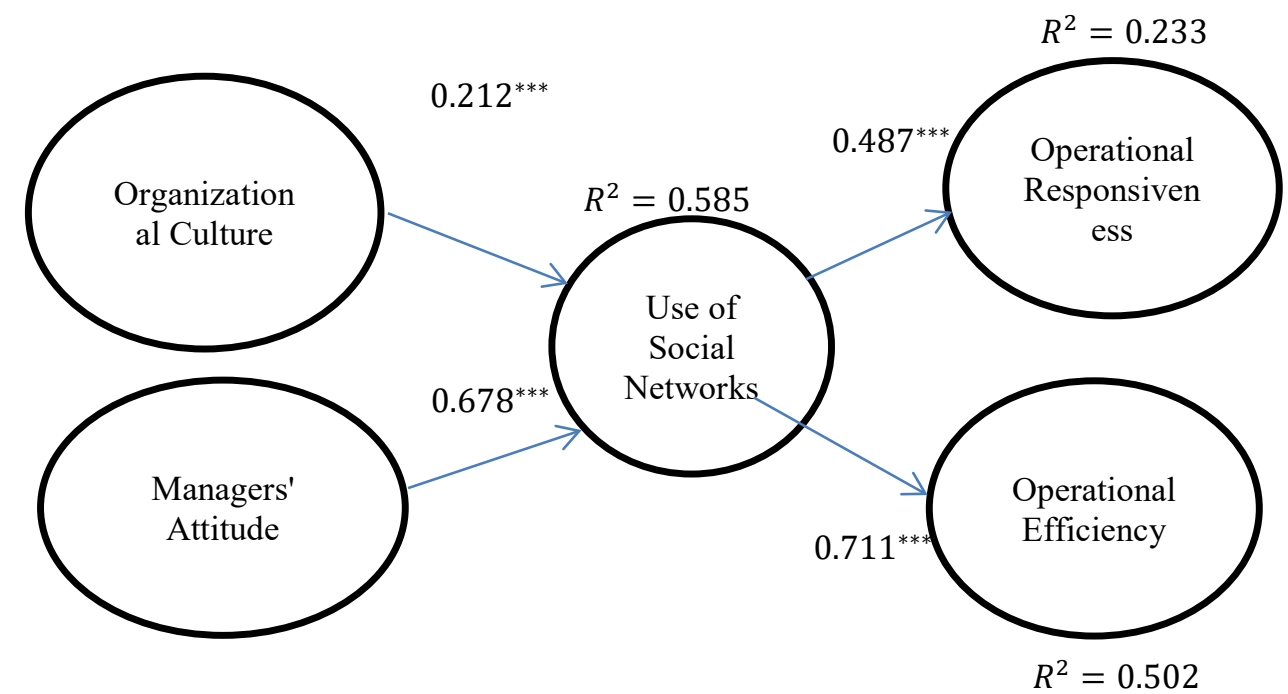

\section{Conclusion}

Figure 2 Research Model Test 
It is given that the use of Social Media for supply chain activities mainly focuses on enhancing marketing and customer relationships and the integration of supply chains. However, there are few studies from organizational and employee perspectives. Therefore, this study aims to see the effect of Managers' attitude and Organizational culture for Social Media usage of supply chain professionals in their supply chain activities.

In essence, this research aims to test a research model of Social Media use in supply chain activities based on the perceptions of Bosnian SMEs' professionals. The results reveal that (a) Managers' Attitude and Organizational Culture are fundamental in adopting Social Media for supply chain activities, and (b) embraced Social Media use have positive influence on Operational Responsiveness and Efficiency.

According to the results, it is observed that the developed framework works well. The companies consider using social Media as advantageous in their supply chain activities. The respondents consider their organizational culture supports using social Media in their business. Therefore, the use of social Media in their business is appeared to be fine. Furthermore, they believe that their operations will be responsive and efficient as a result of Social Media use.

Beside satisfactory support of organizational culture and managers' attitude for Social Media use, they are not so high. However, they use Social Media for their supply chain activities. The reason for this result may be their personal Social Media Use through smart phones among friends in their internal operations while there is a weak information sharing platform among the external supply chain members (suppliers and customers). Their high operational efficiency may explain this deduction. On the other hand, they probably do not use Social Media among external chain members. Therefore, their supply chain is effective but it is not so high. We may also assume that they may not have a supply chain integration software program. Or the program may not be properly implemented for their use. From this perspective, we may suggest Social Media platforms as supportive for their implemented or non-implemented supply chain integration tools.

This study does not test the model for voluntary social media use or obligatory social media use. Since social media platforms are relatively new in business, they are not well developed systems for companies and their supply chains. Therefore, we assume that the use of social media is voluntary for the surveyed professionals. Future research may consider voluntary/obligatory settings.

There are several managerial implications of this study as well. First of all, managers should support organizational climate to use the determined tools to achieve operational responsiveness and efficiency. Future research may examine the behavior of companies from different industries or different subject groups within 
the company. Finally, this research serves as a good basis/template for similar future studies especially in $\mathrm{BiH}$ environment.

As Tang et al. (2019) suggest the companies will have always-connected work environment. Social Media use will be obviously beneficial for this purpose. Therefore, supply chain managers should set clear guidelines and develop training programs regarding social media use for work purposes.

\section{References}

Ang, L. (2011) "Is SCRM really a good social, media strategy?", Journal of Database Marketing \& Customer Strategy Management, vol. 18, no. 3: 149-153.

Aral, S., Dellarocas, C. \& Godes, D. (2013) "Introduction to the special issue-social media and business transformation: a framework for research", Information Systems Research, vol. 24, no.1: 3-13.

Avdagić M., Šabić Z., \& Zaimović T. (2008) "Promoting and Strengthening SME Creation: Use of Franchise Model", Proceedings of 4th International Conference: An Enterprise Odyssey: Tourism - Governance and Entrepreneurship, Cavtat, Croatia.

Bensaou, M. (1999) "Portfolios of buyer-supplier relationships", Sloan Management Review, vol. 40, no. 4: 35-44.

Casemore, S. (2012) "Social Media and the Coming Supply-Chain Revolution", CFO: Retrieved from http://ww2.cfo.com/supply-chain/2012/02/socialmedia-and-the-coming-supply-chain-revolution/

Cavazotte, F., Lemos, A.H. \& Villadsen, K. (2014) "Corporate smart phones: professionals' conscious engagement in escalating work connectivity", New Technology, Work and Employment, vol. 29, no. 1: 72-87.

Chae, B.K. (2015) "Insights from hashtag \#supplychain and Twitter analytics: considering Twitter and Twitter data for supply chain practice and research", International Journal of Production Economics, vol. 165, 247-259, available at: https://doi.org/10.1016/j.ijpe.2014.12.037

Chan, H.K., Lacka, E., Yee, R.W.Y. \& Lim, M.K. (2017) "The role of social media data in operations and production management", International Journal of Production Research, vol. 55, no. 7: 5027-5036.

Chen, I. J., Paulraj, A., \& Lado, A. A. (2004) "Strategic purchasing, supply management, and firm performance", Journal of Operations Management, vol. 22, no. 5: 505-523.

Cheng, H.-L. (2010) "Seeking knowledge or gaining legitimacy? Role of social Media on new practice adoption by OEM suppliers", Journal of Business Research, vol. 63, no. 8: 824-831. http://doi.org/10.1016/j.jbusres. 2009.09.023. 
Choi, T. Y., \& Hong, Y. (2002) "Unveiling the structure of supply Media: case studies in Honda, Acura, and Daimler Chrysler", Journal of Operations Management, vol. 20, no. 5: 469- 493.

Christopher, M. (1998) "Logistics and Supply Chain Management", Harlow: Pearson Education Publishing.

Dimitrijevic, Z., \& Rodic, G. (2011) "Public report on the analysis of SMEs and stakeholders' needs, requirements and feedback to overcome barriers for research \& innovation activities in Bosnia and Herzegovina", European Commission, Research Directorate-General, under FP7-SME-2009-1, SP4Capacities.

Dyer, J. H., \& Singh, H. (1998) "The relational view: Cooperative strategy and sources of interorganizational competitive advantage", Academy of Management Review, vol. 23, no. 4: 660-679.

Elghannam, A., \& Mesias, F. (2019) "Short food supply chains from a social media marketing perspective: a consumer-oriented study in Spain" New Medit, vol. 18, no. 1: 79-90. https://doi.org/10.30682/nm1901g

Elghannam, A., Arroyo, J., Eldesouky, A., \& Mesias, F. J. (2018) "A cross-cultural consumers' perspective on social media-based short food supply chains", British Food Journal, vol. 120, no. 10: 2210-2221. https://doi.org/10.1108/BFJ-11-2017-0633

Enders, A., Hungenberg, H., Denker, H.P. \& Mauch, S. (2008) "The long tail of social networking.: revenue models of social networking sites", European Management Journal, vol. 26, no. 3: 199-211.

Gadde, L.-E., \& Snehota, I. (2000) "Making the most of supplier relationships", Industrial Marketing Management, vol. 29, no. 4: 305-316.

Gebremikael, F., Szmerekovsky, J. G., \& Enyinda, C. (2020) "Ahp based Framework in Driving Intelligence from Social Media to Improve Organizational Performance: An Exploratory Study", Journal of Business and Behavioral Sciences, vol. 32, no. 2: 156-172.

Gunasekaran, A., Patel, C., \& Tirtiroglou, E. (2001) "Performance measure and metrics in a supply chain environment", International Journal of Operations \& Production Management; vol. 21, no. 1/2: 71-87.

Hadžić, M., \& Pavlović, P. (2012) "Small and innovative companies successfully adjusted to crisis circumstances, only", 10th International Conference on Management, Enterprise and Benchmarking (pp. 97-113). Budapest, Hungary: MEB 2012.

Huo, B., Han, Z., Chen, H. \& Zhao, X. (2015) "The effect of high-involvement human resource management practices on supply chain integration", International Journal of Physical Distribution \& Logistics Management, vol. 45, no. 8: 716-746.

Hutchins, J. \& Rodriguez, D.X. (2018) "The soft side of branding: leveraging emotional intelligence", Journal of Business \& Industrial Marketing, vol. 33, no. 1: 117-125. 
IPA National Programme. (2009) "IPA National Programme 2009 Part II - Bosnia and Herzegovina, Fiche 8 "SME Support", Retrieved from http://ec.europa.eu/: http://ec.europa.eu/enlargement/pdf/bosnia_and_herzegovina/ipa/2009/ipa_2 009_part_ii_08_sme_support_en.pdf

Jiang, B., Baker, R.C. \& Frazier, G.V. (2009) "An analysis of job dissatisfaction and turnover to reduce global supply chain risk: evidence from China", Journal of Operations Management, vol. 27, no. 2: 169-184.

Kaplan, A., \& Haenlein, M. (2010) Users of the world, unite! The challenges and opportunities of Social Media. Business Horizons, vol. 53, no. 1: 59-68.

Lam, H.K., Yeung, A.C. \& Cheng, T.E. (2016) "The impact of firms' social media initiatives on operational efficiency and innovativeness", Journal of Operations Management, vol. 47-48, 28-43.

Leonardi, P., \& Vaast, E. (2016) "Social media and their affordances for organizing: a review and agenda for research", Academy of Management Annals, vol. 11, no. 1:150-188. https://doi.org/10.5465/annals.2015.0144

Loiacono, E. \& McCoy, S. (2018) "When did fun become so much work: the impact of social media invasiveness on continued social media use", Information Technology \& People, vol. 31, no. 4: 966-983.

Markova, S., \& Petkovska-Mirčevska, T., (2013) Social media and supply chain. Amfiteatru Economic, vol. 15, no. 33: 89-102.

McAfee, A. P. (2006) "Enterprise 2.0: The Dawn of Emergent Collaboration", MIT Sloan Management Review, vol. 47, no. 3: 21-28.

Mullan, K. \& Wajcman, J. (2019) "Have mobile devices changed working patterns in the 21st century? A time-diary analysis of work extension in the UK", Work, Employment and Society, vol. 33, no. 1: 3-20.

O'leary, D. E. (2011) "The Use of Social Media in the Supply Chain: Survey and Extensions: Use of Social Media in the Supply Chain", Intelligent Systems in Accounting, Finance and Management, vol. 18, no. 2-3: 121-144. http://doi.org/10.1002/isaf.327

OECD (2010) “OECD”, Retrieved 01 29, 2013, from http://www.oecd.org: http://www.oecd.org/daf/privatesectordevelopment/43469926.pdf

O'Reilly, T. (2005) "What Is Web 2.0, Design Patterns and Business Models for the Next Generation of Software", O'Reilly, Retrieved from: http://www.oreilly.com/pub/a/web2/archive/what-is-web-20.html

Ozkul, A., \& Barut, M. (2009) "Measuring supply chain relationships: a social network approach", International Journal of Integrated Supply Management; vol. 5, no. 1: 38-61.

Perez-Luno, A., Bojica, A.M. \& Golapakrishnan, S. (2019) "When more is less: the role of cross-functional integration, knowledge complexity and product innovation in firm performance", International Journal of Operations \& Production Management, vol. 39, no. 1: 94-115.

Quinton, S. \& Wilson, D. (2016) "Tensions and ties in social media networks: towards a model of understanding business relationship development and 
business performance enhancement through the use of LinkedIn", Industrial Marketing Management, vol. 54, 15-24, available at: https://doi.org/10.1016/j.indmarman.2015.12.001

Ramos, L., \& Young, G.O. (2009) "The social technographics of business buyers", Forrester research, Cambridge, MA, February, 20.

Reiss-Davis, Z. (2013) "In Business, Everyone Uses Social Media for Work; The Question is How", Forrester Blogs. http://blogs.forrester.com/zachary_reiss davis/13-07-17-in_business_everybody_uses_social_media_for_work_the question_is_how.

Richardson, K. \& Benbunan-Fich, R. (2011) "Examining the antecedents of work connectivity behavior during non-work time", Information \& Organization, vol. 21, no. 3: 142-160.

Salo, J. (2017) "Social media research in the industrial marketing field: review of literature and future research directions" Industrial Marketing Management, vol. 66.

SCC (Supply Chain Council). (2010) "Supply Chain Operations Reference (SCOR) Model, Version 10”, The Supply Chain Council, Inc. 856p.

Serbetcioglu, C., \& Göçer, A. (2020) "Examining social media branding profiles of logistics service providers", Journal of Business \& Industrial Marketing, 35, no. 12: 2023-2038. https://doi.org/10.1108/JBIM-09-2019-0399

Shang, S.S.C.,Wu, Y.L. \& Li, E.Y. (2017) "Field effects of social media platforms on information-sharing continuance: do reach and richness matter?", Information \& Management, vol. 54, 241-155.

Swain, A. K., \& Cao, R. Q. (2019) "Using sentiment analysis to improve supply chain intelligence", Information Systems Frontiers, vol. 21, no. 2: 469-484. https://doi.org/10.1007/s10796-017-9762-2

Tang, G., Ren, S., Chadee, D., \& Yuan, S. (2019) "The dark side of social media connectivity: Influence on turnover intentions of supply chain professionals", International Journal of Operations \& Production Management, vol. 40, no. 5: 603-623. https://doi.org/10.1108/IJOPM-05-2019-0391

Todaystrucking. (2014, August 1) "Supply chain lagging in use of social media: consultant", Retrieved from www.todaystrucking.com: http://www.todaystrucking.com/supply-chain-lagging-in-use-of-socialmedia-consultant

Tóth, Z., Liu, M., Luo, J., \& Braziotis, C. (2019) "The role of social media in managing supplier attractiveness: An investigation of business-to-business markets", International Journal of Operations \& Production Management, vol. 40, no. 5: 625-646. https://doi.org/10.1108/IJOPM-04-2019-0321

Tybout, A.M. \& Sternthal, B. (2001) "Brand Positioning in Iacobucci, D., (ed.), Kellogg on Marketing", John Wiley, New York, 31-57.

UNECE. (2010) "UNECE", www.unece.org. Retrieved 01 29, 2013, from http://www.unece.org/ fileadmin/DAM/ceci/publications/fie.pdf 
UNIDO. (2007) “UNIDO”. Retrieved 01 29, 2013, from http://www.unido.org: http://www.unido.org/fileadmin/media/images/resized/Private_Sector_CSR/ csr_Development_of_Corporate_Social_Responsibility_in_CEE.pdf

USAID. (2009) "egateg.usaid.gov", Retrieved 1 29, 2013, from USAID: http://egateg.usaid.gov/sites/default/files/SME\%20Finance_Primer_0.pdf

van Zoonen, W., Verhoeven, J.W.M. \& Vliegenthart, R. (2017) "Understanding the consequences of public social media use for work", European Management Journal, vol. 35, no. 5: 595-605.

Yee, R.W.Y., Yeung, A.C.L. \& Cheng, T.C.E. (2008) "The impact of employee satisfaction on quality and profitability in high-contact service industries", Journal of Operations Management, vol. 26, no. 5: 651-668.

Zhang, J., \& Piramuthu, S. (2016) "Product recommendation with latent review topics", Information Systems Frontiers, 1-9. doi:10.1007/s10796-016-9697-z

Zsidisin, G., Ragatz, G. \& Melnyk, S. (2005) "The dark side of supply chain management", Supply Chain Management Review, vol. 9, no. 2: 46-52. 